\title{
Qualitative Assessment of Basel III Liquidity Standards and its Application
} in the UAE

\author{
Manoj Kapur \\ DBA Research Scholar \\ SP Jain School of Global Management, Mumbai, India \\ E-mail: manoj.m.kapur@gmail.com \\ Arindam Banerjee $P h D$ \\ Associate Professor, Finance and Accounting \\ SP Jain School of Global Management, Dubai, UAE \\ E-mail: arin_006@yahoo.com \\ Kunjana Malik $P h D$ \\ Assistant Professor, NMIMS Mumbai, India \\ E-mail: kunjanamalik.phd@fms.edu
}

Received: August I2, 2020

Accepted: August 25, 2020

Online Published: September I3, 2020

doi: 10.4628I/ijfb.v4i2.765

URL: https://doi.org/I0.4628I/ijfb.v4i2.765

\begin{abstract}
The Basel Committee for Banking and Supervision (BCBS) introduced two key liquidity ratios to strengthen the short- and long-term liquidity positions of the banks around the globe. These ratios were designed to achieve two key distinct objectives. Firstly, to encourage banks' short-term resilience to the liquidity risks by ensuring there are sufficient high-quality liquid assets to survive a significant stress which may last for 30 days. Calculation of this ratio is called as Liquidity Coverage Ratio (LCR). Secondly, to promote bank resilience over a longer time horizon, at least annually, by creating additional incentives for banks to fund their activities with more stable sources of funding. This led to creation of Net Stable Funding Ratio (NSFR). While these structural ratios are mostly quantitative, the underlying factors that are needed to calculate these ratios include qualitative factors as well. The paper analyzed the implementation of Basel III standards for the banking sector in the UAE. In particular, the timelines specified by the Central bank of the UAE and its implementation by the Domestic-Systemically Important Banks (D-SIBs) in the UAE was tracked by this paper. The study found a disconnect between the disclosure requirements by Basel III and disclosure made in the published annual financial statements of the banks. The study also discussed the extent of disclosures made by the D-SIBs and how relevant disclosures may improve the transparency of the liquidity risk management of the bank.
\end{abstract}

Keywords: Basel III, Liquidity Coverage Ratio, Net Stable Funding Ratio, UAE, Basel Committee.

JEL Classification Codes: E58, G32, G38.

\section{Introduction}

Basel Accord is a voluntary, global regulatory framework that prescribes capital adequacy, stress testing and market liquidity risk. The third installment of the Accords was developed to address the deficiencies of the financial regulation which led to financial crises of 2007-08. Basel III intended to strengthen the capital requirements of the bank by improving liquidity and reducing leverage, thereby seeking to mitigate the risk of a run on the bank. Wellink (20II) stated the main intention to design Basel III was to address the weakness highlighted in the past crises and prepare the overall banking sector for any future crises. He reiterated a number of reasons which had led to the liquidity crises in 2008, some of which notably were:

- High leverage and very few capital buffers and inadequate quality liquid assets;

- Procyclical deleveraging process and interconnectedness of systemically important financial institutions that were considered too big to fail;

- Limitations in sound governance practices, risk management strategies, board compensations for risk taking activities and lapses in supervision by the Central Banks.

Basel III introduced two key liquidity ratios, namely: The Liquidity Coverage Ratio (LCR) in January 20I3, to measure the short term and Net Stable Funding Ratio (NSFR) in October 20I4, to measure the long-term liquidity position of the bank. These structural ratios were introduced as a means to act as shock absorbers for liquidity. From the 
Basel perspective, both these ratios were subject to an observation period and would be mandatory after this observation period.

A similar approach was adopted in the UAE, where these ratios were adopted to manage the liquidity positions of the banking sector. Given the nature of UAE markets where expats are $80 \%$ of the total population as well as funding requirements are reliant mainly on the Government, it is important to manage liquidity requirements prudently Basel III Liquidity Management requires consideration of the following vital factors as long-term funding opportunities are limited in the UAE:

- Time and cost involved,

- The requirement to hold more high liquid and short-term low yielding assets impacting return on earnings,

- Uncertainty about availability of high-quality liquid assets, and;

- An increase in funding cost.

CBUAE (2015) introduced these ratios through a Regulation and an explanatory circular which emphasized the role of banks by providing maturity transformation of lending long term and borrowing short term. The objective of the regulation was to ensure that banks have a robust liquidity risk management and governance processes to mitigate the risk of this imbalance in maturity transformation.

Both these ratios were in a transitionary period from 2016 until 2019, when full compliance was expected to be achieved. The glide path basis was as follows:

TableI. Liquidity Ratios transitionary compliance from 2016 to 2019

\begin{tabular}{lllll}
\hline Ratio & I January 20I6 & I January 20I7 & I January 20I8 & I January 2019 \\
\hline Minimum LCR & $70 \%$ & $80 \%$ & $90 \%$ & $100 \%$ \\
\hline Minimum NSFR & -- & -- & $100 \%$ & $100 \%$ \\
\hline
\end{tabular}

Both these ratios must be complied on an ongoing basis and are required to be calculated daily. But the reporting of the ratio as mandated by the Central Bank of the UAE is monthly for LCR and quarterly for NSFR.

CBFSR (2018) stated that Basel III liquidity framework was mainly targeted for large internationally active banks and alternate liquidity framework (viz Eligible Liquid Asset ratio and Advances to Stable Deposit Ratio) for all the other banks. In 20I8, four banks in the UAE were granted Basel III Liquidity regime compliance and were accordingly required to comply with the Central Bank Regulation on Liquidity. These banks were categorized as Domestically - Systemically Important Banks (DSIBs) by the Central Bank of the UAE and were obliged to hold additional capital to ensure soundness and stability of themselves as well as that of the UAE banking system. The four DSIB banks are First Abu Dhabi Bank (FAB), Emirates NBD bank (ENBD), Abu Dhabi Commercial Bank (ADCB) and Dubai Islamic Bank (DIB). There has been a steady increase in statistical analysis done by the long-term Central Bank since 2016 to identify the criterial to be included to classify banks in DSIB categories. Based on technical and fundamental research of the past data, Central Bank proposed five-point criteria to judge the DSIBs in the UAE. Four criteria were directly adopted by the recommendations made by the Basel Committee for Banking Supervision (BCBS) which included size of the bank in terms of total ass ets, interconnectedness to the international markets, substitutability to variety of jurisdictions and complexity of products/ processes and operations. Central Bank of the UAE decided to ass another overlay namely the Supervisory overlay as an additional criterion to benchmark these to the UAE local market specifics. DSIB assessment covered national banks at their consolidated group level; whereas foreign banks at their UAE branch level. Based on the criterial identified, three banks were identified as DSIBs in 20I7. In 2018, a fourth bank also fulfilled the DSIB criteria and was added to the group because of its DSIB score exceeding CBUAE predetermined threshold. This bank was Dubai Islamic Bank (DIB), which is the oldest Islamic bank in the world. Based on an assessment conducted by the Central Bank in Q4 20I8, all four designated D-SIBs viz: $\mathrm{FAB}, \mathrm{ENBD}, \mathrm{ADCB}$ and $\mathrm{DIB}$ remained at their assigned levels of additional DSIB capital buffers as per the CBUAE assessment. For the year 2018, LCR for UAE banks averaged I26\% while NSFR was still in the early adoption days

The primary objective of this study is to qualitatively assess the liquidity risk management requirements disclosed by the DSIBs in their annual financial statement. In addition, if any disclosure was made in the stock market through investor presentations will also be verified. The author will utilize secondary data published by the following DSIBs in the UAE:

- First Abu Dhabi Bank (FAB)

- Emirates NBD Bank (ENBD)

- Abu Dhabi Commercial Bank (ADCB)

- Dubai Islamic Bank (DIB)

The important and the primary research question that needs to be answered via this qualitative research is: How and to what extent are DSIBs disclosing the liquidity risk management framework (in specific the Basel III ratios) of their bank in the UAE?

\section{Literature Review}

Liquidity risk arises when the long-term assets are getting funded by short term liabilities thereby leading to an asset liability mismatch. Kumar and Yadav (2013) studied the liquidity risk management framework in banks and stated that liquidity 
risk is dependent on individual characteristics of each financial institution. Hence it is unique based on the way an institution operates and specializes. In an unwarranted situation when there is premature withdrawal of deposits, liquidity provides that buffer which is essential to keep the institution on a going concern basis. In order to categories an individual institutions liquidity risk, the cash flows are segregated into separate time zones depending on their maturity profile. Since liquidity is dynamic in nature, it will be linked to other aspects of the financial statements including market risk, interest rate, equity and profitability. If the bank has larger liquid assets, it might improve the equity but the cost of holding liquidity may reduce the amount of profitability. Hence every institution is obligated to calculate that optimum level of liquidity required to avoid liquidity risk.

Singh and Sharma (2016) contradicted that liquidity risk is usually of an individual nature and stated that facts need to be looked from a broader perspective. Based on the panel data analysis for selected Indian banks, macroeconomic factors including inflation had a positive impact on the liquidity and GDP had a negative impact on liquidity. Cost of funding and unemployment had an insignificant effect on banks liquidity. Several other studies have been conducted to confirm that macro-economic factors do play a significant role in determining the liquidity risk for the banks.

Based on the idiosyncratic and macro-economic factors, the authors list some internal and external factors in the banks in UAE, that may potentially lead to liquidity risk in banks:

Table 2. List of idiosyncratic and macro-economic factors affecting banks liquidity

\begin{tabular}{|c|c|}
\hline Idiosyncratic Factors & Macro-Economic Factors \\
\hline Excessive off-balance sheet funding in the form of LCs/ LGs & $\begin{array}{l}\text { High concentration of price sensitive financial markets } \\
\text { depositors }\end{array}$ \\
\hline Concentration of short-term deposits from the corporates & Low to very slow economic performances \\
\hline Inadequate gap analysis for assets and liabilities. & $\begin{array}{l}\text { Low depositors' trust on the banking sector due to } \\
\text { mismanagement in certain banks }\end{array}$ \\
\hline $\begin{array}{l}\text { Rapid asset expansion and diversification strategy exceeding } \\
\text { the funds availability }\end{array}$ & Non-economic factors \\
\hline Concentration of deposits in the short-term bucket & $\begin{array}{l}\text { Sudden and massive liquidity withdrawals from depositors } \\
\text { leading to banks going bust }\end{array}$ \\
\hline $\begin{array}{l}\text { Low investment in high quality liquid asset especially } \\
\text { government bonds }\end{array}$ & Unplanned termination of government deposits. \\
\hline Fewer placements in long-term deposits & External and internal economic shocks. \\
\hline
\end{tabular}

Chen, Shen, Kao, and Yeh (2018) studied the banks liquidity risk and their performance using data of 12 advanced economies commercial bank from 1994 to 2006. Their study included another dimension by considering supervisory and regulatory factors over and above the macro-economic and external factors. The study found the relation between liquidity risk and banks net interest margin. It stated that the bank's profitability would be decreased if there are higher costs of funds due to increase in liquidity risk. This would also simultaneously increase the bank's net interest margin. The results were revolutionary, in a way, as the theory paved way for the financial system to be classified into two broad categories bank based financial system and market based financial system. Based on these classifications it was ascertained that there is a negative relation between bank performances in the market based financial system. The study proved that in the bank based financial system; there was no impact to the liquidity risk. The concept related to bank based or market based depends on the type of countries these banks are incorporated. Countries where bank based financial system is prevalent, there was greater effort made to rely on bank finance as these intermediaries would aid in mustering public savings, allocating capital, overseeing the investment decisions of corporate managers, and in providing risk management vehicles. On the other hand, countries having market based financial would involve greater focus on developing its stock market finance and securities markets which would inter-alia share center stage with banks in terms of getting society's savings to firms, exerting corporate control, and easing risk management. Bank based countries included France, Germany, Italy, etc. whereas Market-based countries included Australia, Canada, Japan, Luxembourg, Netherlands, Switzerland, Taiwan, United Kingdom, United States of America, etc.

BCBS (2008) published in February 2008, Liquidity Risk Management and Supervisory Challenges for managing liquidity risk. The difficulties outlined in that paper highlighted that many banks did not foresee that liquidity could be an issue which would affect its operation, given that it was available in abundance before 2008. As a result, there were very few liquidity risk measures undertaken by the banks especially relating to stress testing the product and business lines. Many banks also had misaligned the incentive package for the businesses and sales department with the risk strategy of the bank. Banks did not foresee that extent of liquidity required for meeting the obligation of contingent funding either contractual or non-contractual, as they viewed funding of these obligations to be highly unlikely. In order to avoid further catastrophes in future, BCBS propounded core minimum liquidity risk management principles which would aid banks to tackle liquidity problems. The following is the synopses of the liquidity risk management principles: 
Table 3. Fundamental principles for the management and supervision of liquidity risk

Principle I $\quad$ "A bank is responsible for the sound management of liquidity risk. A bank should establish a robust
liquidity risk management framework that ensures it maintains sufficient liquidity, including a cushion of
unencumbered, high quality liquid assets, to withstand a range of stress events, including those involving
the loss or impairment of both unsecured and secured funding sources. Supervisors should assess the
adequacy of both a bank's liquidity risk management framework and its liquidity position and should take
prompt action if a bank is deficient in either area in order to protect depositors and to limit potential
damage to the financial system."

Based on the paper published by BCBS in 2008 on sound principles of liquidity risk management, Vento \& La Ganga (2009) studied the lessons learnt from the market turmoil of 2008. One of the limitations highlighted was of the differences in the regulatory regimes across several countries. While some supervisors had strict regulations around establishment of liquidity risk management framework others were based on best practices ad principles. These differentiated practices created arbitrage in the implementation of standardized framework across several countries. In light of these differences, national regulators would continue to apply differentiated practices which would lead to different disclosures made by the licensed institutions. It would also lead to issues relating to comparability of high-quality liquid assets, decoding stress events for stress testing of liquidity as well as determining diversified source of funding.

Table 4. Governance of liquidity risk management

\begin{tabular}{ll}
\hline Principle 2 & "A bank should clearly articulate a liquidity risk tolerance that is appropriate for its business strategy and \\
& its role in the financial system." \\
\hline Principle 3 & "Senior management should develop a strategy, policies and practices to manage liquidity risk in \\
accordance with the risk tolerance and to ensure that the bank maintains sufficient liquidity. Senior \\
management should continuously review information on the bank's liquidity developments and report to \\
the board of directors on a regular basis. A bank's board of directors should review and approve the \\
strategy; policies and practices related to the management of liquidity at least annually and ensure that \\
senior management manages liquidity risk effectively." \\
"A bank should incorporate liquidity costs, benefits and risks in the internal pricing, performance \\
measurement and new product approval process for all significant business activities (both on- and off- \\
balance sheet), thereby aligning the risk-taking incentives of individual business lines with the liquidity \\
risk exposures their activities create for the bank as a whole."
\end{tabular}

Chung, Elder, and Kim (2010) studied the relation of corporate governance and liquidity; specifically, stock market liquidity. According to their research findings, corporates had better liquidity management techniques if there was adequate governance in place. Superior corporate governance lead to higher market quality index, narrow spreads leading to long term liquidity measures over governance index. It further provided that good corporate governance alleviated investor confidence as transparency measures were adopted by the firms.

Good corporate governance standards improve operational and financial transparency and aids to protect shareholder interest. Prior research suggests that firms with poor governance have lower market capitalization as inadequately protected shareholders right leads to insignificant cashflow from the shareholder. This was confirmed by Gompers, Ishii, and Metrick (2003) where corporate with poorer shareholders had lower profit margin and stagnated growth in sales. The findings are different when the results are compared for family owned businesses. Firms run by family businesses are more conservative and have stricter practices for managing liquidity than banks and non-family managed firms. These firms exhibit higher volume of liquidity and lower risk to liquidity. Kapur $\left(2020_{a}\right)$ conducted a graphical ratio analysis between the performance of conventional and Islamic Banks. Among the several ratios, the liquidity ratio of both type of banks were compared to analyze the liquidity adequacy of Islamic and conventional banks. While governance was not a decisive factor, the study found the conventional banks to have diversified source of liquidity and higher investment in liquid assets since Islamic banks were considered conservative as far as lending was concerned due to strict Sharia laws. This was substantiated in a further research conducted by Kapur (2020b) wherein detailed quantitative assessment was conducted between conventional and Islamic banks using correlation and regression analysis.

Table 5. Measurement and management of liquidity risk

\begin{tabular}{ll}
\hline Principle 5 & "A bank should have a sound process for identifying, measuring, monitoring and controlling liquidity \\
& $\begin{array}{l}\text { risk. This process should include a robust framework for comprehensively projecting cash flows arising } \\
\text { from assets, liabilities and off-balance sheet items over an appropriate set of time horizons. " }\end{array}$ \\
\hline Principle 6 & "A bank should actively monitor and control liquidity risk exposures and funding needs within and \\
& across legal entities, business lines and currencies, taking into account legal, regulatory and operational \\
\hline
\end{tabular}


limitations to the transferability of liquidity."

Principle 7 "A bank should establish a funding strategy that provides effective diversification in the sources and tenor of funding. It should maintain an ongoing presence in its chosen funding markets and strong relationships with funds providers to promote effective diversification of funding sources. A bank should regularly gauge its capacity to raise funds quickly from each source. It should identify the main factors that affect its ability to raise funds and monitor those factors closely to ensure that estimates of fundraising capacity remain valid."

Principle 8 "A bank should actively manage its intraday liquidity positions and risks to meet payment and settlement obligations on a timely basis under both normal and stressed conditions and thus contribute to the smooth functioning of payment and settlement systems."

Principle 9 "A bank should actively manage its collateral positions, differentiating between encumbered and unencumbered assets. A bank should monitor the legal entity and physical location where collateral is held and how it may be mobilized in a timely manner."

Principle I0 "A bank should conduct stress tests on a regular basis for a variety of short-term and protracted institution-specific and market-wide stress scenarios (individually and in combination) to identify sources of potential liquidity strain and to ensure that current exposures remain in accordance with a bank's established liquidity risk tolerance. A bank should use stress test outcomes to adjust its liquidity risk management strategies, policies, and positions and to develop effective contingency plans."

Principle II "A bank should have a formal contingency funding plan (CFP) that clearly sets out the strategies for addressing liquidity shortfalls in emergency situations. A CFP should outline policies to manage a range of stress environments, establish clear lines of responsibility, include clear invocation and escalation procedures and be regularly tested and updated to ensure that it is operationally robust."

Principle I2 "A bank should maintain a cushion of unencumbered, high quality liquid assets to be held as insurance against a range of liquidity stress scenarios, including those that involve the loss or impairment of unsecured and typically available secured funding sources. There should be no legal, regulatory or operational impediment to using these assets to obtain funding."

Prior to the pronouncement of Basel II - Risk based capital measurement; regulators addressed the quantification and measurement of risks impacting the bank as a whole and not just a part of balance sheet. Even though liquidity risk management was not part of Basel II, the intention of the Regulators was to protect the integrity of the entire banking sector. This led to the publication of sound principles of liquidity risk management. Measurement and stress testing liquidity was an integral part of this publication. Since the financial crises of 2008, liquidity has always taken center stage for many banks and financial institution. Banks are required to assess liquidity requirements on an ongoing basis to ensure they continue as a going concern. In order to ensure this, banks are formally required to draft Contingency Funding Plan, which should address the liquidity requirements during stressed times. A CFP includes policies, procedures and action plans designed to ensure that the banks' source of liquidity is adequate for normal operating requirements of the bank. In a book published by Lai and Tuosto(2016), CFP serves as a logical companion and has a connection to liquidity stress test framework. CFP helps to link the results of the stress test with other related information as a guide to CFP framework, contingent liability actions and governance. CFP provides a structured approach for developing and implementing the firm's financial and operational strategies for effectively managing several contingent liquidity events during period of financial crises and stress.

Table 6. Public disclosure

Principle I3 "A bank should publicly disclose information on a regular basis that enables market participants to make an informed judgement about the soundness of its liquidity risk management framework and liquidity position."

Based on the above principles a sound liquidity risk management system would include the following benchmarks followed by the banks:

- The bank should ensure to establish a liquidity framework which is considered to be robust and rigorous in nature.

- Articulating a liquidity risk strategy which is commensurate with the business model, size and complexity of the bank must be the responsibility of the Board of Directors (BoD) of the bank

- This strategy must be reviewed annually to ensure it is current and up to date. Any changes in the strategy must be communicated to the relevant stakeholders.

- Senior management as well as Asset Liability Committee (ALCO) should proactively review information on bank's liquidity developments and report to the board of directors on a regular and more preferably on a quarterly basis. 
- A bank should have a robust process to identify, measure, monitor and control liquidity risk which includes a framework for extrapolating cash flows that arise out of assets, liabilities and off-balance sheet items over a defined time horizon.

- The liquidity needs of the bank must cover short/ medium- and long-term horizon and must sufficiently cover its funding needs.

- It is imperative for the bank to measure and consider cost and benefit analysis of internal pricing, and liquidity cost in new product approval or existing product performance measurement for all relevant activities of business.

- Liquidity should be managed across groups, legal entities, currencies and business lines. Banks should monitor and manage liquidity and funding risk taking into account regulatory and operational requirements across several jurisdictions.

- A bank should diversify its funding base to avoid concentration from single depositor or group of depositors with similar characteristics and establish funding strategy in this regard.

- The treasury department of the bank must ensure that markets are proactively tested for access of liquidity. Any deviation must be immediately notified to the senior management and Board as an escalation.

- A bank should ascertain alternative funding source that would strengthen its capacity to survive severe idiosyncratic and macro level liquidity stress.

- A bank should proactively consider managing its intra-day liquidity risks and positions.

- A bank should proactively consider managing its collateral positions to ensure liquidity.

- A bank should conduct stress tests at regular intervals and consider variety of scenarios which could include idiosyncratic (bank specific) as well as macro-economic (market specific) factors and use these outcomes to channel its liquidity strategy, policies as well as to develop its CFPs.

- It is the duty of the Risk department to monitor potential stress situations through EWI (Early Warning Indicators). These can be used as trigger events to invoke CFP for the banks. Basel as well as the Central Bank of UAE has defined series of EWI that can be utilized by the banks as a means to avoid significant deterioration of the financial position.

- To moderate the potential for reputation risk, a bank should have adequate systems to communicate with the counterparties, Regulators, government, credit rating agencies as well as other stakeholders when liquidity crisis arise.

- Banks should have well-articulated CFP that sets out the strategies to be considered during liquidity shortfalls during liquidity stress scenarios. The policies must also include the defined roles and responsibilities entrusted on the people during a stress situation.

- A bank should maintain sufficient buffer of unencumbered and high-quality liquid assets which can be utilized during an adverse situation or financial deterioration.

- To boost transparency the bank must adopt the disclosure requirements promulgated by the Basel Committee for Banking Supervision to publicly disclose its liquidity management on a regular or annually basis in its financial statements. This mechanism will ensure that market participants are well informed and are aware of any liquidity issues in a financial institution.

\section{Data and Methodology}

BCBS (2014) issued Liquidity Coverage Ratio Disclosure Standards to improve transparency of these regulatory ratios and reinforce sound principles, enhance market discipline and reduce uncertainty in the markets as LCR is implemented. As per the Basel requirements, the disclosure of the Liquidity coverage ratio should follow a common template so as to ensure comparability among peer group banks. The template clearly reflects the disclosure requirements and how/what the banks are required to publish in their annual financial statements. The committee cautioned some challenges associated with disclosure of liquidity position under certain situations including potential dynamic changes during the period of stress where the liquidity is expected to reduce. Hence, the committees' consideration included certain disclosure limitation which the institutions can utilize in disclosing liquidity reports.

BCBS (2015) issued Net Stable Funding Ratio disclosure standards to focus on the disclosure requirements for NSFR. Similar to LCR, the intention of these standards was to improve the transparency of the regulatory funding requirement and reinforce the sound principles of liquidity risk management, enhance market discipline and reduce uncertainties during the implementation phase of NSFR.

In addition to the usual template mentioned in the standard, the banks are required to publicly disclose qualitative discussion surrounding the computation of LCR to facilitate the understanding of the results generated and the data required. These are the minimum requirements but where the banks want to disclose additional data, it could do it in the annual financial statements. 
Table 7. LCR disclosures as per Basel BCBS 272

\begin{tabular}{|c|c|}
\hline Sr No & Disclosures requirements under Liquidity Coverage Ratio Disclosure Standards \\
\hline $\mathrm{I}$ & Is the common template as prescribed by BCBS 272 used to disclose calculation of LCR? \\
\hline 2 & $\begin{array}{l}\text { Qualitative discussion on: } \\
\text { (a) the main drivers of their LCR results and the evolution of the contribution of inputs to the LCR's } \\
\text { calculation over time; } \\
\text { (b) intra-period changes as well as changes over time; } \\
\text { (c) the composition of HQLA; } \\
\text { (d) concentration of funding sources; } \\
\text { (e) derivative exposures and potential collateral calls; } \\
\text { (f) currency mismatch in the LCR; } \\
\text { (g) a description of the degree of centralization of liquidity management and interaction between the } \\
\text { (h) other inflows and outflows in the LCR calculation that are not captured in the LCR common template } \\
\text { but which the institution considers to be relevant for its liquidity profile. }\end{array}$ \\
\hline 3 & $\begin{array}{l}\text { Disclosure of other quantitative and qualitative information will provide market participants with a broader } \\
\text { picture of banks' liquidity risk position and management and promote market discipline }\end{array}$ \\
\hline 4 & $\begin{array}{l}\text { disclose additional quantitative information related to its internal liquidity risk measurement and management } \\
\text { framework }\end{array}$ \\
\hline 5 & $\begin{array}{l}\text { Several key monitoring tools for assessing liquidity risk like } \\
\text { (a) contractual maturity mismatch; } \\
\text { (ii) concentration of funding; } \\
\text { (iii) available unencumbered assets; } \\
\text { (iv) LCR by significant currency; and } \\
\text { (v) market-related monitoring tools. }\end{array}$ \\
\hline
\end{tabular}

These metrics are not regulatory requirements under the Basel III framework, but may be used as consistently defined monitoring tools. They are intended to capture specific information related to a bank's cash flows, balance sheet structure and available collateral.

6 The additional quantitative information that banks may consider disclosing could include customized measurement tools or metrics that assess the structure of the bank's balance sheet, as well as metrics that project cashflows and future liquidity positions, taking into account off-balance sheet risks which are specific to that bank

$7 \quad$ Other quantitative information could include key metrics that management monitors, including, but not limited to:

(a) concentration limits on collateral pools and sources of funding (both products and counterparties);

(b) liquidity exposures and funding needs at the level of individual legal entities, foreign branches and subsidiaries, taking into account legal, regulatory and operational limitations on the transferability of liquidity; and

(c) balance sheet and off-balance sheet items broken down into maturity buckets and the resultant liquidity gaps.

8 Banks may also choose to provide other qualitative information to enable market participants to gain a more thorough understanding of internal liquidity risk management and positions, particularly those related to that specific institution. This information could include:

(a) governance of liquidity risk management, including: risk tolerance; structure and responsibilities for liquidity risk management; internal liquidity reporting; and communication of liquidity risk strategy, policies and practices across business lines and with the board of directors;

(b) funding strategy, including policies on diversification in the sources and tenor of funding, and whether the funding strategy is centralized or decentralized;

(c) liquidity risk mitigation techniques;

(d) an explanation of how stress testing is used; and

(e) an outline of contingency funding plans.

9 Additional information that banks choose to disclose should provide sufficient information to enable market participants to understand and analyze any figures provided. 
Table 8. NSFR disclosure as per Basel BCBS 324

\begin{tabular}{ll}
\hline \multicolumn{1}{c}{ Disclosures requirements under Net Stable Funding Ratio Disclosure Standards } \\
\hline I & The disclosure of quantitative information about the NSFR should follow the common template developed by \\
the BCBS 324 dated June 20I5
\end{tabular}

The author acknowledges that the calculation of these ratios is purely structural and it could only be one measure of the banks' funding risk and that other qualitative and quantitative information would be essential for market participants to gain broader picture of the banks funding mix and management. This study will analyze the financial statements of the UAE banks to ascertain if Basel III Liquidity disclosures are done by the sampled banks. The author will not go into the details of the calculation and quantify if these ratios have been accurately calculated.

A similar study was conducted by Asongu (2013) to investigate post crises measures adopted by the banks to manage liquidity risk. The study based its reliance on Basel II Pillar 3 disclosures made by 20 of the top 33 world banks on liquidity risk management. The research purely analyzed the annual financial statements of the banks regarding development of a structure for managing liquidity, Measurement and management of net funding requirement, Management of market access and contingency planning and role of internal control, supervisors and public disclosure in improving liquidity management. The study found that approximately $25 \%$ of the banks were transparent when it came to disclosing liquidity risk management; which clearly indicated that banks did not considered liquidity as an important factor even after several guidance issued by the Basel committee. The following can be considered as scope limitation for this paper which can be covered through future research:

- Verifying the calculation and impact of several factors on liquidity coverage ratio and net stable funding ratio

- Conducting interview with risk managers/ financial controllers of banks to understand first-hand the reporting and disclosure requirements

- Market impact and changes in share price in case the liquidity falls below the regulatory threshold.

Further, the author will utilize secondary data sources like annual published financial statements to ensure the extent of disclosure requirements are met by the sampled DSIB banks in the UAE.

Liquidity Risk and its management disclosed by First Abu Dhabi Bank (FAB) in the Annual Financial Statement as at 31 December 2018:

Table 9. Excerpts from Annual Audited Financial Statements

\begin{tabular}{|c|c|}
\hline $\begin{array}{l}\text { Page No of the Annual Financial } \\
\text { Statement }\end{array}$ & Liquidity Risk disclosure \\
\hline Page 68 & $\begin{array}{l}\text { "FAB manages liquidity at group level and has defined the liquidity risk appetite so as } \\
\text { to ensure that the Group has a controlled liquidity risk position with adequate cash or } \\
\text { cash-equivalents to be able to meet its financial obligations, in all foreseeable } \\
\text { circumstances and without incurring substantial additional costs, for a rolling period of } \\
\text { three months." }\end{array}$ \\
\hline Page 68 & $\begin{array}{l}\text { "The risk appetite is supported by a comprehensive risk management framework that } \\
\text { includes Group ALCO approved limits for key funding and liquidity metrics, stress } \\
\text { testing and a contingency funding plan." }\end{array}$ \\
\hline Page 69 & $\begin{array}{l}\text { "One of the critical means to measure adequacy of liquidity as per extant global } \\
\text { regulation is through Liquidity Coverage Ratio (LCR). FAB is internally reporting } \\
\text { Basel III LCR numbers for a considerable period of time, and has invested heavily in } \\
\text { ensuring systems and controls framework is in place to comply with all the qualitative } \\
\text { and quantitative aspects of Basel III. LCR as at 3I December } 2018 \text { stood at I I8\%, } \\
\text { much higher than the minimum ratio prescribed by the Regulator, Central Bank of the } \\
\text { UAE. In addition, the Group also ensures that it is compliant with UAE Central Bank } \\
\text { liquidity regulation on Eligible Liquid Assets Ratio (ELAR) at all times." }\end{array}$ \\
\hline Page 69 to 72 & $\begin{array}{l}\text { "FAB has disclosed the contractual maturity mismatch of assets and liabilities } \\
\text { considering the groups retention history." }\end{array}$ \\
\hline $\begin{array}{l}\text { Page } 7 \text { of Basel Pillar } 3 \\
\text { disclosures }\end{array}$ & $\begin{array}{l}\text { "The bank has listed Global Asset Liability Committee (GALCO) as one of the } \\
\text { management committee that assists the BOD and Board Committees in fulfilling its } \\
\text { responsibility to oversee the Group's asset and liability management (ALM) related }\end{array}$ \\
\hline
\end{tabular}


responsibilities. GALCO is directly accountable to the Board Risk Committee for ensuring that the risks within the Group Asset and Liability position are prudently managed by way of strong Group policy and procedures and an appropriate risk framework. The objective of GALCO is balance sheet management design and strategy and constant oversight of interest rate risk and liquidity risk with the primary goal of achieving optimal return while ensuring adequate levels of liquidity within an effective risk control framework."

"In order to ensure the bank has robust risk management culture at the bank, FAB has a centralized risk management function - Group Risk Management which is led by the GCRO. The function comprises of Enterprise Risk Management Unit, Credit Risk Management Unit, Operational Risk Management Unit, Fraud Risk Management Unit, Market \& Liquidity Risk Management Unit, Information Security \& Business Continuity Management, Group Compliance, Group Legal \& Corporate Governance and Risk Integration and Portfolio Analytics unit. It is the nerve center for collection of data, analysis of risk drivers, interpretation of outcome and its wide dissemination to relevant committees for risk management.

December 2018

Liquidity Risk and its management disclosed by Emirates NBD (ENBD) in the Annual Financial Statement as at 3I

Table I0. Excerpts from Annual Audited Financial Statements

\begin{tabular}{|c|c|}
\hline $\begin{array}{c}\text { Page No of the Annual Financial } \\
\text { Statement }\end{array}$ & Liquidity Risk disclosure \\
\hline Page I2I & $\begin{array}{l}\text { "ENBD has a group liquidity management framework. The objective of the Group's } \\
\text { liquidity and funding management framework is to ensure that all foreseeable funding } \\
\text { commitments (under both normal and stressed conditions) can be met when due, and } \\
\text { that access to the wholesale markets is coordinated and cost effective. To this end, the } \\
\text { Group maintains a diversified funding base comprising core consumer and corporate } \\
\text { customer deposits and institutional balances. This is augmented with wholesale funding } \\
\text { and portfolios of highly liquid assets diversified by currency and maturity which are } \\
\text { held to enable the Group to respond quickly and smoothly to unforeseen liquidity } \\
\text { requirements." }\end{array}$ \\
\hline Page I2I & $\begin{array}{l}\text { "Liquidity and funding management process includes: } \\
\text { projecting cash flows under various stress scenarios and considering the level } \\
\text { of liquid assets necessary in relation thereto; } \\
\text { mis-match analysis between assets and liabilities for different periods with a } \\
\text { focus on shorter time frames. These gap reports are based on contractual cash } \\
\text { flow, retention and decay assumptions for non- maturing assets and liabilities } \\
\text { and potential liquidity demand through undrawn commitments; } \\
\text { monitoring balance sheet liquidity and advances to deposits ratios against } \\
\text { internal and regulatory requirements; } \\
\text { maintaining a diverse range of funding sources with back-up facilities; } \\
\text { managing the concentration and profile of debt maturities; } \\
\text { maintaining debt financing plans; } \\
\text { monitoring customer depositor concentration in order to avoid undue } \\
\text { reliance on large individual depositors and ensure a satisfactory overall } \\
\text { funding mix; and } \\
\text { maintaining liquidity and funding contingency plans. These plans identify } \\
\text { early indicators of distress conditions and describe actions to be taken in the } \\
\text { event of difficulties arising from systemic or other crisis, while minimizing } \\
\text { adverse long-term implications for the business" }\end{array}$ \\
\hline Page I22 & "maturity profile of the Group's assets and liabilities based on their carrying value" \\
\hline
\end{tabular}


Liquidity Risk and its management disclosed by Abu Dhabi Commercial Bank (ADCB) in the Annual Financial Statement as at 3I December 2018:

Table II. Excerpts from Annual Audited Financial Statements

\begin{tabular}{ll}
\hline $\begin{array}{l}\text { Page No of the Annual Financial } \\
\text { Statement }\end{array}$ & Liquidity Risk disclosure \\
\hline Page 2I & The bank has provided an overview of banking sector liquidity. It stated "Banking
\end{tabular}
sector liquidity remained ample as the loan-to-deposit ratio declined to a four-year low, reflecting the outpacing of deposit growth to credit growth. The key driver for this liquidity was higher Government deposits, which reached a multi-year high in 2018 as the price of oil increased. Government related entities (GREs) also helped to strengthen total net deposits to underpin liquidity across the sector. This liquidity is helping to limit the positive spread between the EIBOR and LIBOR rates from historical levels, though they have widened from the small differential seen in early 2018. Meanwhile, the UAE Central Bank continued to raise benchmark rates in line with the US Federal Reserve."

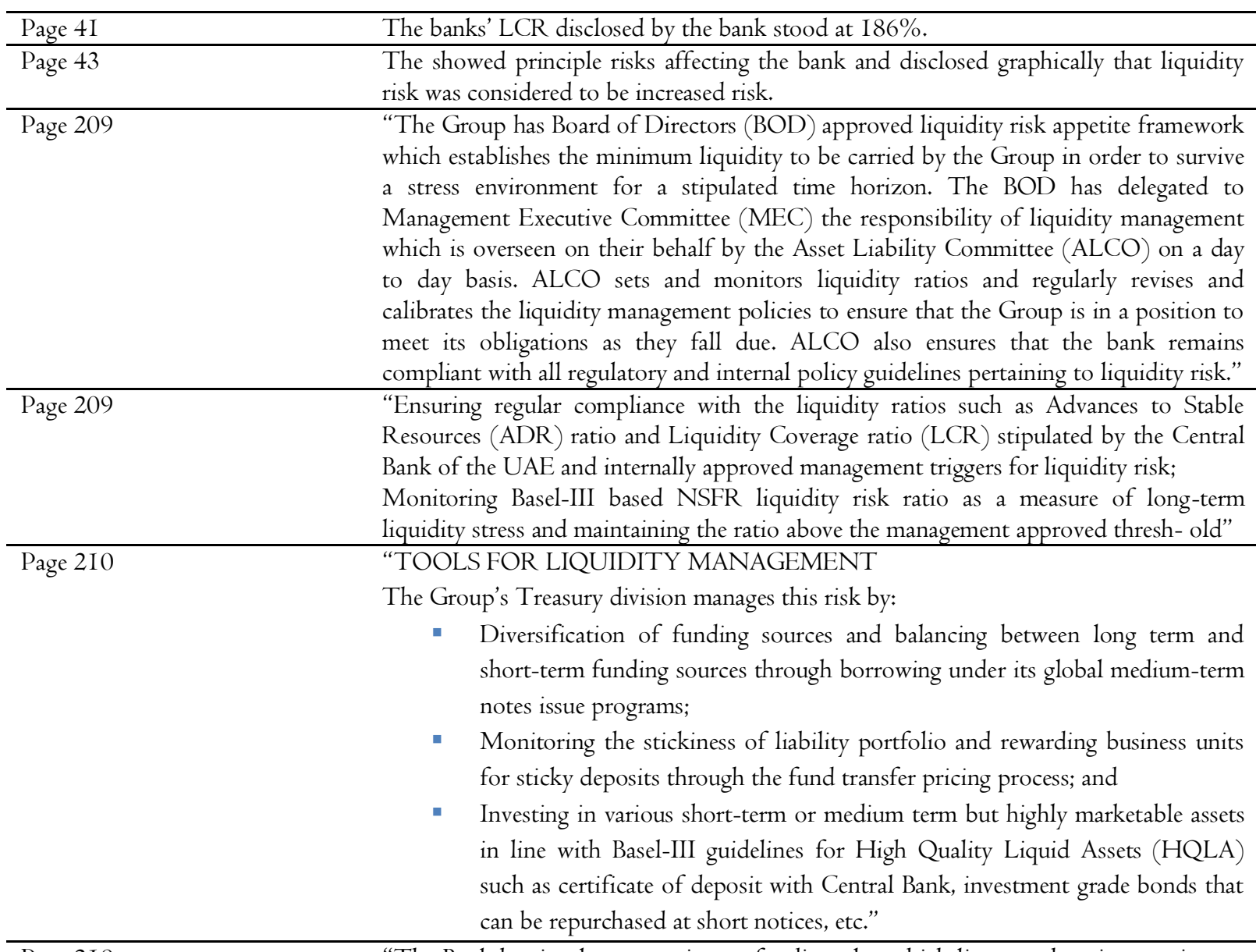

Page 2I0 "The Bank has in place a contingent funding plan which lists out the trigger points to be monitored for invoking the contingent funding plan. The trigger points are based on market observable data points like credit spreads and internal and external events like decline in customer deposits and drying up of wholesale markets. The contingent funding plan clearly defines the roles and responsibilities and is updated with changing market conditions by ALCO.

The maturity profile is monitored by management to ensure adequate liquidity is maintained" 
Liquidity Risk and its management disclosed by Dubai Islamic Bank (DIB) in the Annual Financial Statement as at 3I December 20I8:

Table 12. Excerpts from Annual Audited Financial Statements

\begin{tabular}{|c|c|}
\hline $\begin{array}{c}\text { Page No of the Annual Financial } \\
\text { Statement }\end{array}$ & Liquidity Risk disclosure \\
\hline Page 83 & $\begin{array}{l}\text { "Asset and Liability Management Committee ("ALCO") is responsible for managing } \\
\text { the Group's assets and liabilities and the overall financial structure. It is also primarily } \\
\text { responsible for the funding and liquidity risks of the Group." }\end{array}$ \\
\hline Page 84 & $\begin{array}{l}\text { "In order to guard against liquidity risk, management has diversified funding sources } \\
\text { and assets are managed with overall liquidity in consideration maintaining a healthy } \\
\text { balance of liquid assets (i.e. cash and cash equivalents)." }\end{array}$ \\
\hline Page 90 & $\begin{array}{l}\text { "The Group maintains a portfolio of highly marketable and diverse assets that can be } \\
\text { easily liquidated in the event of an unforeseen interruption of cash flow. The Group } \\
\text { also has committed lines of credit that it can access to meet liquidity needs. In addition, } \\
\text { the Group maintains statutory deposits with the central banks. The liquidity position is } \\
\text { assessed and managed under a variety of scenarios, giving due consideration to stress } \\
\text { factors relating to both the market in general and specifically to the Group. } \\
\text { The high quality of the asset portfolio ensures its liquidity and coupled with the } \\
\text { Group's own funds and stable customer deposits help form a stable funding source. } \\
\text { Even under adverse conditions, the Group has access to the funds necessary to cover } \\
\text { customer needs and meet its funding requirements." }\end{array}$ \\
\hline Page 90 & $\begin{array}{l}\text { "The Group liquidity risk management process, as carried out within the } \\
\text { Group and monitored by a separate team in Group Treasury department, } \\
\text { includes: } \\
\text { " Monitoring future cash flows to ensure that requirements can be met. This } \\
\text { includes replenishment of funds as they mature or are financed by customers; } \\
\text { Maintaining a portfolio of highly marketable assets that can easily be } \\
\text { liquidated as protection against any unforeseen interruption to cash flow; } \\
\text { " Monitoring financial position liquidity ratios against internal and regulatory } \\
\text { requirements; } \\
\text { Managing the concentration and profile of Islamic financing and investing } \\
\text { exposures maturities; and } \\
\text { Monitoring liquidity ratios" }\end{array}$ \\
\hline Page 9I & "Maturity profile of assets and liabilities..." \\
\hline
\end{tabular}

\section{Results and Conclusion}

Liquidity risk management is an inevitable part of every bank and other financial institution. For any financial institution to function as going concern, it is important that adequate level of liquidity be maintained at all times. While Basel III highlights a new approach to liquidity risk management and its disclosure requirements, which is not as flexible as and stricter than Basel II, it is important that banks adopted these requirements whole heartedly and adhere to the disclosure requirements to bring in more transparency. Liquidity Risk being one of the reasons for financial distress should not be ignored. Following the Basel Committee recommendations, drafting an operational liquidity risk management system is the only way to fight out its ill effects. Depression that fled away the Lehman Brothers was just an alarm to the leading developed and developing economies to cry out for such bitter experiences from a time before it strikes again.

The current research was to find out the extent of disclosures done by the DSIBs in the UAE, especially in the area of liquidity risk management. Emphasis was placed on disclosure requirements mentioned by the Basel III - LCR and NSFR requirements which would enable to bring standardization across banks. The research found that banks had selective disclosure requirements for liquidity risk management and standardization was only observed in certain areas viz: maturity profile of assets and liabilities, formation of ALCO and liquidity and funding management process. The following disconnect in the disclosure requirements was observed when comparing the bank's annual financial statement with the Basel III disclosure requirements:

- Some of the banks had disclosed the LCR quantitatively while some refrained from it. None of the DSIBs had disclosed the NSFR even though minimum requirement is to comply with I00\% from I January 20I8;

- None of the DSIBs disclosed the common template for LCR and NSFR as required by BCBS272 and BCBS324. Disclosing the common template would increase transparency of the quantitative requirement;

- Other disclosure requirements relating to the main drivers of their LCR/ NSFR results and the evolution of the contribution of inputs to the ratios calculation over time; intra-period changes as well as changes over time; the composition of HQLA; concentration of funding sources; derivative exposures and potential collateral calls; 
currency mismatch in the ratio; a description of the degree of centralization of liquidity management and interaction between the group's units; and other inflows and outflows in the ratio calculation that are not captured in the common template but which the institution considers to be relevant for its liquidity profile were also not done.

While the findings are useful, it must be considered that the time period under consideration is limited and further research must be conducted by directly collecting primary data from the Chief Risk Officers of the bank. It is important to remind that liquidity risk management is an important indicator of the financial crises, in the UAE banking system as well as globally. While world-wide Basel III is perceived to be successful, the magnitude of its success can only be measured through the disclosures made by the banks. Further research may be conducted to determine the perception of UAE banks regarding analysis of all risk types and the capital buffers required for these identified risks, including liquidity risk. It would also be useful to question the central banks requirements for disclosures as Basel III might not be completed adopted by several countries.

\section{References}

Asongu, S. A. (2013). Post-crisis bank liquidity risk management disclosure. Qualitative research in financial markets.

BCBS, J. (2008). Principles for Sound Liquidity Risk Management and Supervision

BCBS, J. (20I5). Basel III Net Stable Funding Ratio disclosure standards

BCBS, J. (20I4). Basel III leverage ratio framework and disclosure requirements.

CBFSR. (2018). Central Bank Financial Stability Report 2018. Retrieved from https://centralbank.ae/sites/default/files/2019-07/FSR-Report-20I8.pdf

CBUAE. (2015). Central Bank of the UAE Regulation Re Liquidity at Banks, UAE, 2015. Retrieved from https://centralbank.ae/sites/default/files/2018-I2/Liquidity\%20regulation.pdf

Chen, Y. K., Shen, C. H., Kao, L., \& Yeh, C. Y. (2018). Bank liquidity risk and performance. Review of Pacific Basin Financial Markets and Policies, 2I(OI), I850007.

Chung, K. H., Elder, J., \& Kim, J. C. (2010). Corporate governance and liquidity. Journal of Financial and Quantitative Analysis, 45(2), 265-29I.

Gompers, P., Ishii, J., \& Metrick, A. (2003). Corporate governance and equity prices. The quarterly journal of economics, II $8(\mathrm{I})$, I07-I56.

Kapur, M. (2020a). Performance of Conventional and Islamic Banks in the UAE: A Comparative Graphical Ratio Analysis.

Kapur, M. (2020b). An Empirical Study into Comparing Conventional and Islamic Banks in the UAE. International Journal of Accounting \& Finance Review, 5(2), I I-3I. https://doi.org/I0.4628I/ijafr.v5i2.7I6

Kumar, M., \& Yadav, G. C. (2013). Liquidity risk management in bank: a conceptual framework. AIMA journal of management \& research, $7(2), 2-12$.

Lai, C., \& Tuosto, R. (2016). Contingency Funding Planning. Liquidity Risk Management: A Practitioner's Perspective.

Singh, A., \& Sharma, A. K. (2016). An empirical analysis of macroeconomic and bank-specific factors affecting liquidity of Indian banks. Future Business Journal, 2(I), 40-53.

Vento, G. A., \& La Ganga, P. (2009). Bank liquidity risk management and supervision: which lessons from recent market turmoil. Journal of Money, Investment and Banking, IO(I0), 78-I25.

Wellink, N. (20II). Basel III and beyond. High Level Meeting on Better Supervision and Better Banking in a Post-crisis Era. (I-5), FSI and EMEAP Working Group on Banking Supervision (hosted by Bank Negara Malaysia), Kuala Lumpur, Malaysia.

Annual Financial Statement of the Domestic-Systemically Important Banks in the UAE

First Abu Dhabi Bank (FAB), 2018

Emirates NBD (ENBD), 2018

Abu Dhabi Commercial Bank (ADCB), 2018

Dubai Islamic Bank (DIB), 2018

\section{Copyrights}

Copyright for this article is retained by the author(s), with first publication rights granted to the journal. This is an openaccess article distributed under the terms and conditions of the Creative Commons Attribution license (http://creativecommons.org/licenses/by/4.0/). 